\title{
Levels of Selenium in Vegetables, Medicinal Plants and Soils from Selected Sites within the Lower Benue River Basin Development Authority Catchment, Nigeria
}

\author{
Ahola D. Oklo ${ }^{1 *}$, Rufus Sha'Ato ${ }^{2}$, Ishaq S. Eneji ${ }^{2}$, Michael A. Igyor $^{3}$ \\ ${ }^{I}$ Department of Chemistry, Benue State University, PMB 102119, Makurdi, Nigeria \\ ${ }^{2}$ Department of Chemistry, University of Agriculture, PMB 2373, Makurdi, Nigeria \\ ${ }^{3}$ Department of Food Science and Technology, PMB 2373, Makurdi, Nigeria
}

\begin{abstract}
The levels of Selenium (Se) in vegetables, medicinal plants and soils from selected sites within the Lower Benue River Basin Development Authority catchment (spanning latitudes $6^{\circ} 15^{\prime}$ and $9^{\circ} 10^{\prime} \mathrm{N}$ and longitudes $6^{\circ} 22^{\prime}$ and $10^{\circ} 25^{\prime} \mathrm{E}$ ) were determined as part of investigations of the element's biogeochemistry in the area. Seventy eight (78) plant and forty (40) agricultural soil samples were obtained from eight sites in the study area and their levels of Se determined using the simple, sensitive and selective 2, 4-DNPH-NEDA spectrophotometric method. Results obtained showed soil Se in the whole area was in the range $1.0 \times 10^{-4}-97.0$ $\times 10^{-4} \mathrm{mg} / \mathrm{kg}$, with an average of $44.0 \times 10^{-4} \pm 0.0020 \mathrm{mg} / \mathrm{kg}$, while the mean Se levels in vegetables and medicinal plants were $217.0 \times 10^{-4} \pm 0.0105 \mathrm{mg} / \mathrm{kg}$ and $206.0 \times 10^{-4} \pm 0.01 \mathrm{mg} / \mathrm{kg}$ respectively. These results show that Se in the soils and vegetation in the area is lower compared to literature reports. The Lower Benue Valley (LBV; coordinates of longitudes $7^{\circ} \mathrm{O} 0^{\prime} \mathrm{E}$ and $8^{\circ} 30^{\prime} \mathrm{E}$ and latitudes $5^{\circ} 00^{\prime} \mathrm{N}$ and $\left.6^{\circ} 30^{\prime} \mathrm{N}\right)$ in Nigeria where HIV/AIDS prevalence is historically fairly high and considering the role of Se in the progression of this disease we embarked on studies of the phytopedochemical distribution of the element in the areas including LBV.
\end{abstract}

Keywords: Lower Benue River Basin, Nigeria, Plants, Selenium, Soils

\section{Introduction}

Selenium (Se) is an essential micronutrient, necessary for normal function of human and animal physiology. It is incorporated into proteins to make selenoproteins, which are important antioxidant enzymes, vitamins, hormones and other protein tissues which help prevent cellular damage from free radicals resulting from oxygen metabolism. The absences of these antioxidants help contribute to the development of some chronic diseases and play a role in the depression of the immune system [1-6]. Its deficiency in food and feed causes a number of diseases like cancer, cardiomyopathy, myocardial deaths, arthritis, rheumatoid and myxedematous endemic cretinism [7-11]. Se deficiency has also been implicated in the progression of Human Immune Deficiency Syndrome (HIV) infection to full blown Acquired Immune Deficiency Syndrome (AIDS) $[12,13,14]$. Soils, the loose material that cover the land surfaces of earth and supports the growth of plants vary widely from place to place. Many factors determine the chemical composition and physical structure of the soil at any given location [15]. These factors may contribute either to Se accumulation during soil formation or its removal during or after the soil forming process. Selenium abundance in the earth's crust is unevenly distributed and is in the range $<0.05-0.5 \mathrm{mg} / \mathrm{kg}$ [16]. Elemental Se occurs rarely in rocks and soils but it is usually found in the combined state such as sodium selenite, sodium selenate and potassium selenite; therefore, the different kinds of rocks, minerals and other geologic materials from which the soil originally formed plays a role in its Se content and availability [17]. Whereas, soils formed on sedimentary rocks contain high amounts of organic matter and typically have high to toxic Se concentrations, soils formed on magmatic rocks, which are poor in Se, ab initio, usually have a low Se content [18].

Plant foods are the major dietary sources of selenium in most countries of the world and the content of selenium in these food sources depends on the selenium content of the soil where they are grown [19-22]. When we feed on plants and animals that had absorbed a large quantity of Se, selenium level will tend to increase in our systems. People that eat a lot of grains that have been grown near industrial sites may experience a higher exposure to Se through food [23]. In all cases, the selenium content of foods reflects the available selenium content of the soils used to produce those foods and the feedstuffs used to produce livestock.

Some vegetable plants are commonly used for medicinal purposes and plant parts like the roots, stems and leaves are employed for the formulation. Documentation of medicinal use of African plants is becoming increasingly urgent because of the rapid loss of the natural habitat for some of these plants due to anthropogenic activities. In spite of the marginalization of traditional medicine practiced in the past, the attention currently given by governments to widespread health-care application has given a new impetus to research, investment and design of programmes in this field in several developing countries in Africa and elsewhere [24, 25, 26]. 
Studies have shown that selenium concentrations in soils are unreliable and if an accurate determination of selenium intake is needed, Se concentration should be determined for both the agricultural soils which are used for crop productions and the food crops, including vegetables and other vegetation-derived ingestible, like medicinal herbs $[18,27]$. The Lower Benue Valley (LBV; coordinates of longitudes $7^{\circ} 00^{\prime} \mathrm{E}$ and $8^{\circ} 30^{\prime} \mathrm{E}$ and latitudes $5^{\circ} 00^{\prime} \mathrm{N}$ and $6^{\circ} 30^{\prime} \mathrm{N}$ ) in Nigeria where HIV/AIDS prevalence is historically fairly high [28] and considering the role of $\mathrm{Se}$ in the progression of this disease we embarked on studies of the phytopedochemical distribution of the element in the areas including LBV [29,30]. Operations of the Lower Benue River Basin Development Authority LBRBDA include development of land for irrigated agriculture, in its areas of coverage $[31,32]$. Therefore, this paper reports the levels of Se in vegetables, medicinal plants and soils from selected sites in the Lower Benue River Basin Development project area.

\subsection{Description of the Study Area}

\section{Materials And Methods}

The Lower Benue River Basin Development Authority (LBRBDA) Project area lies between latitudes $6^{\circ} 15^{\prime}$ and $9^{\circ} 10^{\prime} \mathrm{N}$ and longitudes $6^{\circ} 22^{\prime}$ and $10^{\circ} 25^{\prime} \mathrm{E}$, spanning the four North Central States of Benue, Plateau, Nasarawa and Kogi. However, this study covered only the Benue-Kogi axis of the project area (Fig. 1). The Authority has the mandate to develop water resources potentials of its catchment for agricultural, industrial and domestic uses, inter alia; some of the crops grown there are potatoes, cassava, soya bean, guinea corn, yams, sesame, rice, ground nuts, fruits and leafy vegetables [33].
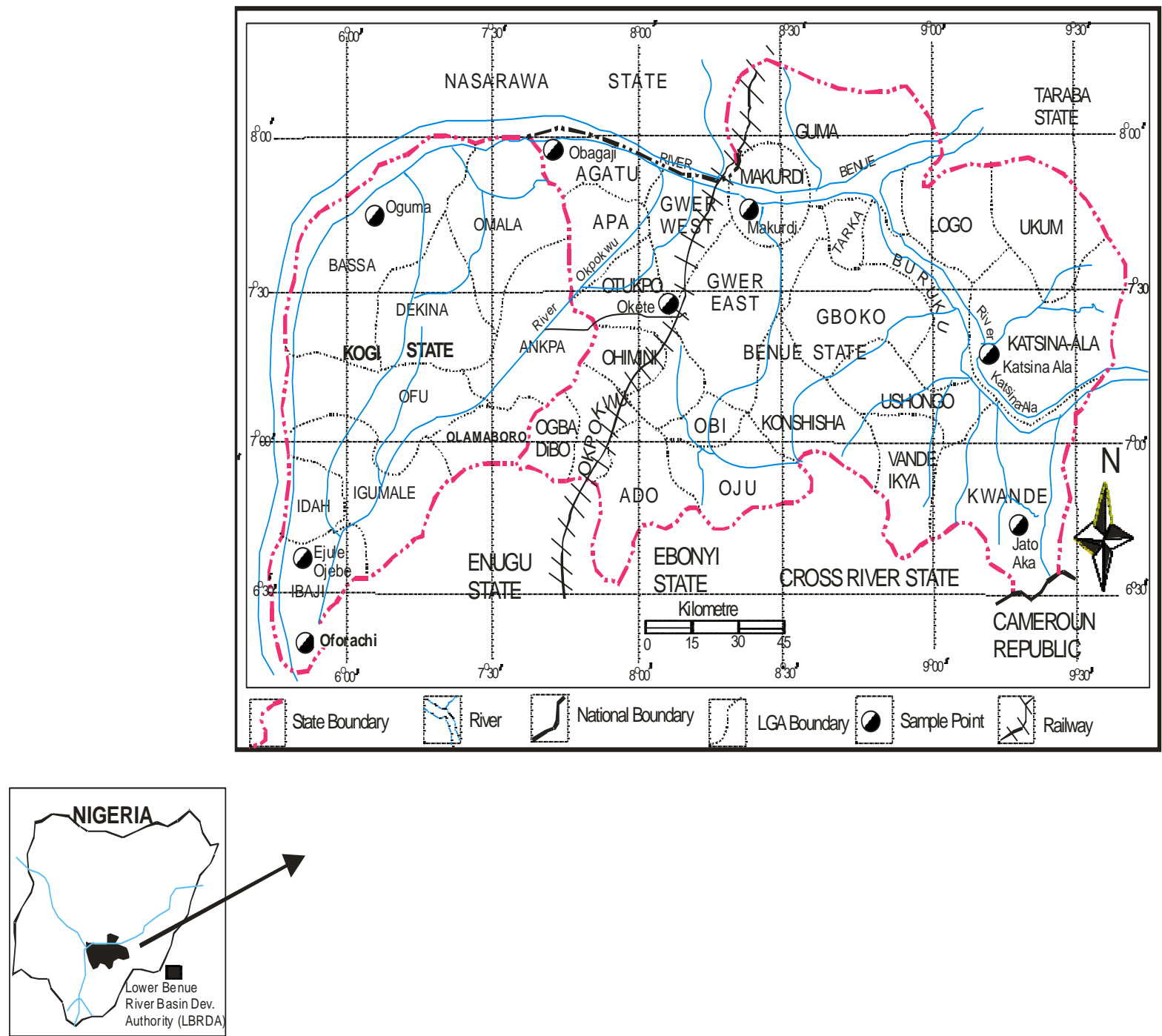

Figure1: map of lower Benue river basin showing sampling points Source: Lower Benue Makurdi, Benue State 
Table 1: Sampling Sites in the LBRBDA Project Area*

\begin{tabular}{|l|l|l|}
\hline Site** & Site Code & Soil Parent Material*** \\
\hline $\begin{array}{l}\text { Oguma } \\
\text { (Bassa LGA) }\end{array}$ & OGM & $\begin{array}{l}\text { Cretaceous Sandstones/Upper Coal } \\
\text { Measures }\end{array}$ \\
\hline $\begin{array}{l}\text { EjuleOjebe } \\
\text { (Ibaji LGA) }\end{array}$ & EJO & $\begin{array}{l}\text { Cretaceous Sandstones/Upper Coal } \\
\text { Measures }\end{array}$ \\
\hline $\begin{array}{l}\text { Oforachi } \\
\text { (Idah LGA) }\end{array}$ & OFO & $\begin{array}{l}\text { Cretaceous Sandstones/Upper Coal } \\
\text { Measures }\end{array}$ \\
\hline $\begin{array}{l}\text { Obagaji } \\
\text { (Agatu LGA) }\end{array}$ & OBG & $\begin{array}{l}\text { Quaternary (River Alluvium Benue) } \\
\text { Cretaceous Sediments (Eze-Aku- } \\
\text { Agwu Formation) }\end{array}$ \\
\hline $\begin{array}{l}\text { Okete } \\
\text { (Makurdi } \\
\text { Makurdi LGA) }\end{array}$ & OKT & Quaternary (River Benue) Alluvium \\
\hline $\begin{array}{l}\text { KatsinaAla } \\
\text { Katsina- Ala LGA) }\end{array}$ & MKD & $\begin{array}{l}\text { Precambrian Basement Complex } \\
\text { rocks }\end{array}$ \\
\hline $\begin{array}{l}\text { Jato Aka } \\
\text { Kwande LGA) }\end{array}$ & KAL & $\begin{array}{l}\text { Precambrian Basement Complex } \\
\text { rocks }\end{array}$ \\
\hline
\end{tabular}

*See Figure 1.

**LGA is Local Government Area (County).

$* * *$ Underlying geology of soil.

Table 2: Scientific names of plant and vegetable selected for the study

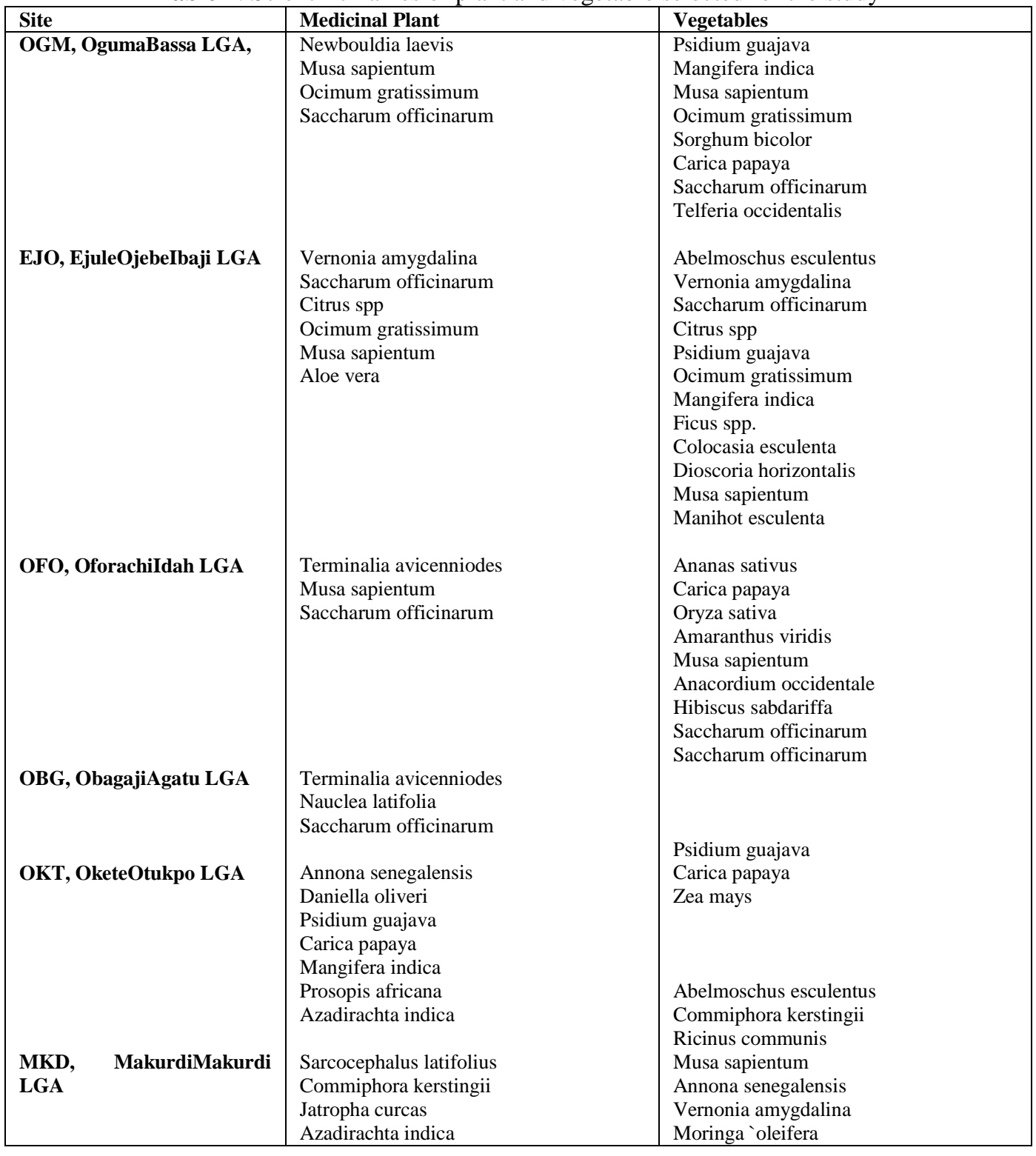




\begin{tabular}{|c|c|c|}
\hline $\begin{array}{l}\text { KAL, KatsinaAla K/ Ala } \\
\text { LGA }\end{array}$ & $\begin{array}{l}\text { Musa sapientum } \\
\text { Jatropha curcas } \\
\text { Vernonia amygdalina } \\
\text { Moringa oleifera } \\
\text { Psidium guajava } \\
\text { Piliostigma thonningii } \\
\text { Ocimum gratissimum } \\
\text { Musa sapientum } \\
\text { Azadirachta indica } \\
\text { Ficus polita } \\
\text { Psidium guajava } \\
\text { Tephrosia vogelii } \\
\text { Senna occidentalis } \\
\text { Carica papaya } \\
\text { Newbould laevis } \\
\text { Ficus polita }\end{array}$ & $\begin{array}{l}\text { Ocimum gratissimum } \\
\text { Musa sapientum } \\
\text { Hibiscus sabdariffa } \\
\text { Psidium guajava } \\
\text { Anacardium occidentale } \\
\text { Arachis hypogaea } \\
\text { Capiscum annuum }\end{array}$ \\
\hline
\end{tabular}

\subsection{Sampling}

Vegetable and soil samples were collected from designated farms sites at the locations indicated in Figure 1; Table 1 gives details of the parent materials (underlying geology) of the soils at the locations and the site codes.

Medicinal plants, Vegetables and soils samples were collected from designated farms and vegetable garden within the project sites, Table 2. At each sampling site, 3-18 medicinal plants and vegetables were randomly collected and identified by a Taxonomist of Benue State University, Makurdi, Nigeria. Seventy eight (78) plant samples - vegetables and medicinal plants were collected using a table knife. Plant parts sampled include; vegetable leaves, stems, nuts, seeds, roots and fruits. Samples were stored in an ice - box and transported to the laboratory.

At least 3-6 soil samples were randomly taken from each of the site using a hand trowel. Samples were collected from each of the sampling sites within the months of July, 2011 to August, 2013 continuously. Soil samples were obtained at a depth of $0-20 \mathrm{~cm}$. Forty (40) soil samples were collected for investigation. Samples were stored in a black labeled polyethylene bags and transported to the laboratory where they were air dried at room temperature prior to preparation and analysis.

\subsection{Sample Digestion}

\subsubsection{Plant samples}

Exactly $2.0 \mathrm{~g}$ of finely chopped fresh plant sample was placed in a $250 \mathrm{~mL}$ beaker and $10 \mathrm{~mL}$ of a $1: 1$ $(\mathrm{v} / \mathrm{v})$ mixture of concentrated sulphuric acid and nitric acid were added. This mixture was placed on a heating mantle and heated for approximately fifteen minutes until the solution became clear. This was then brought down and allowed to cool; on cooling, the solution (digestate) was filtered and concentrated to $5 \mathrm{~mL}$ by evaporative heating on the mantle. The cooled, concentrated digestate was made up to $50 \mathrm{~mL}$ in standard volumetric flask with distilled water and kept for Se determination.

\subsubsection{Soil samples}

Two grams $(2.0 \mathrm{~g})$ of the sieved air-dried soil sample was weighed into a $100 \mathrm{~mL}$ beaker and $10 \mathrm{~mL}$ of concentrated nitric acid added. This mixture was heated to near dryness on a heating mantle. Another $10 \mathrm{~mL}$ of concentrated $\mathrm{HNO}_{3}$ was added to the residue which was allowed to cool and was subsequently filtered. Ten (10) millilitres concentrated hydrochloric acid was added to the filtrate and heated to expel chlorine and oxides of nitrogen. The concentrated solution was diluted to $50 \mathrm{ml}$ with distilled water and kept for Se determination.

In each of the digestion procedures, inorganic and organic-bound selenium was oxidized to Se (IV) ion. Reagent blank solutions were prepared for soil and vegetable samples using the same procedures but without the sample.

\subsection{Standard Procedure for Determination of Se in Sample Solution \\ 2.4.1 Theoretical background}

A rapid, simple, sensitive and selective method for the determination of traces of selenium (IV) ion in environmental samples, introduced by Krishnaiah et al., (2003), was employed. It is based on the reaction between $\mathrm{Se}^{+4}$ and 2, 4-DNPH-NEDA reagent in which oxidation 2, 4- dinitrophenyl hydrazine hydrochloride (2,4-DNPH) by selenium (IV) ion in an acidic medium is followed by a coupling reaction between $(2,4-$ dinitrophenyl) diazene formed from the oxidation and $\mathrm{N}$-(1-naphthyl) ethylenediamine (NEDA) to give pink coloured product which absorbs strongly in the visible region at $520 \mathrm{~nm}$ (Scheme I); this forms the basis of Se determination by UV-Visible spectrophotometry [34]. 


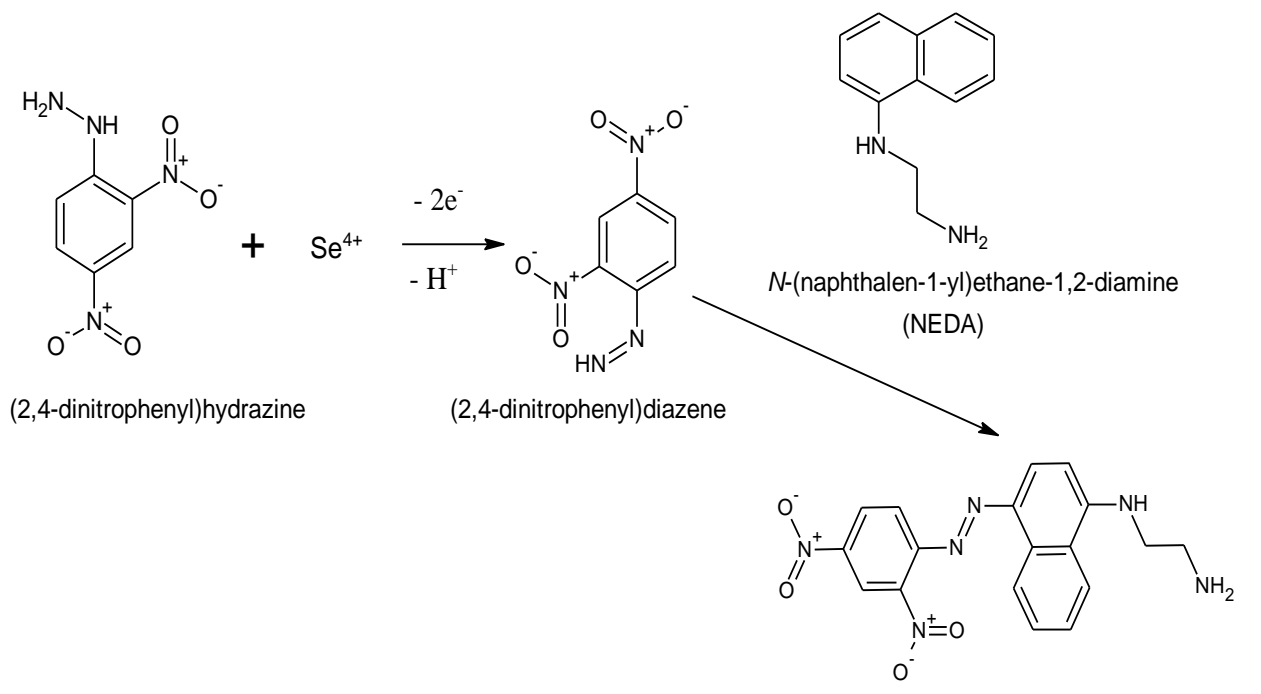

$N-\{4-[(E)-(2,4-d i n i t r o p h e n y l)$ diazenyl]naphthalen-1-yl\}ethane-1,2-diamine

Scheme I: Analytical reaction on which the UV-vis spectrophotmetric method is based

\section{Reagents and chemicals}

All the chemicals used were of at least 95.5\% purity. They were obtained from Zayo-Sigma Chemicals Limited, Jos, Nigeria (a division of Sigma - Aldrich Advancing Science, United Kingdom) and were used without purification. They include: 2, 4- dinitrophenyl hydrazine hydrochloride (2, 4-DNPH), N-(1-naphthyl) ethylenediaminedihydrochloride (NEDA), Selenium, hydrochloric acid and sulphuric acid.

\section{Preparation of reagent mixtures (Krishnaiah et al., 2003)}

A $1.5 \%$ 2,4-DNPH-NEDA reagent mixture was prepared by dissolving $1.0 \mathrm{~g}$ of NEDA and $0.5 \mathrm{~g}$ of 2,4-DNPH and adding $10 \mathrm{~mL}$ of concentrated $\mathrm{HCl}$ in water which was made up to $100 \mathrm{~mL}$ and refrigerated at $\sim 10^{\circ} \mathrm{C}$. Distilled water was used to prepare all solutions in the experiments.

\section{Standard selenium stock solution}

A stock solution $100 \mathrm{ppm}$ of selenium solution was prepared by dissolving about $0.10 \mathrm{~g}$ elemental selenium powder in $10 \mathrm{~mL}$ of conc. $\mathrm{HNO}_{3}$. After dissolution was complete, it was transferred into a 1-L flask and diluted to volume with distilled water. The selenium is in the +4 valence state $\left(\mathrm{H}_{2} \mathrm{SeO}_{3}\right)$. This solution was diluted 1:100 to prepare a 1-ppm solution. Series of standards containing 0.01, 0.02, 0.04, 0.06, 0.08, $0.10 \mathrm{ppm}$ was prepared by diluting the 1 -ppm solution.

\section{UV - Vis Spectrophotometric procedure}

Exactly $50 \mathrm{~mL}$ of the diluted sample solution containing $\mathrm{Se}^{+4}$ was transferred into $250 \mathrm{~mL}$ calibrated flat bottom flask. Five milliliter concentrated $\mathrm{HCl}$ and $2.0 \mathrm{~mL}$ 2, 4-DNPH-NEDA reagent mixtures were added and allowed to stand for $10 \mathrm{mins}$. The contents were diluted to the $250 \mathrm{~mL}$ mark with distilled water and run at $\lambda$ max $520 \mathrm{~nm}$ using a SHIMADZU UV 2550 Spectrophotometer. A blank was run similarly. Concentrations of Se in the aliquots measured were obtained from the calibration curve (Absorbance $=5.76 \times 10^{-4} \times[\mathrm{Se}] ; \mathrm{R}^{2}=0.9984$ ) constructed using standard Se (IV) solutions.

\section{Analytical data quality assurance}

The method of analyte recovery was adopted for analytical data quality assurance using leaf of Annona senegalensis. Exactly $2.0 \mathrm{~g}$ of finely chopped fresh leaves of Annona senegalensis leaf sample was placed in a $250 \mathrm{~mL}$ beaker spiked with one gram $(1.0 \mathrm{~g})$ elemental selenium and was treated with $10 \mathrm{~mL}$ of a $1: 1(\mathrm{v} / \mathrm{v})$ mixture of concentrated sulphuric acid and nitric acid. This mixture was heated. Heating continued for approximately fifteen $(\sim 15 \mathrm{~min}$.) minutes until solution became clear. On cooling, the solution (digestate) was filtered and concentrated to $5 \mathrm{~mL}$ by continuous heating. The cooled concentrated digestate was made up to 50 $\mathrm{mL}$ in standard volumetric flask with distilled water and the standard procedure applied to the solution. Exactly $2.0 \mathrm{~g}$ of previously chopped fresh leaves of same Annona senegalensis leaf sample was placed in a $250 \mathrm{~mL}$ beaker but without spiking, was passed through same procedures and unspiked concentration obtained was subtracted from spiked concentration; results were expressed as percentage: 
$\%$ Recovery $=\frac{\mathrm{Sc}-\mathrm{USc}}{\mathrm{Sc}} \times 100$

Where: Sc $=$ Spiked Concentration

USc $=$ Unspiked Concentration

\section{Data analysis}

Data collected were subjected to statistical test of significance using percentage, t-test, standard deviation, mean, simple correlation coefficient matrix to assess significant variation in concentration levels of Se across the various samples. Statistical analysis was done using SPSS.

\subsection{Results}

\section{Results And Discussion}

Results of Se concentration in vegetables and medicinal plants from selected sites of the Lower Benue River Basin Development Authority (LBRBDA) project sites are shown in Figure 2. The results are considered in the context of the $82 \%$ recovery obtained in the recovery study.

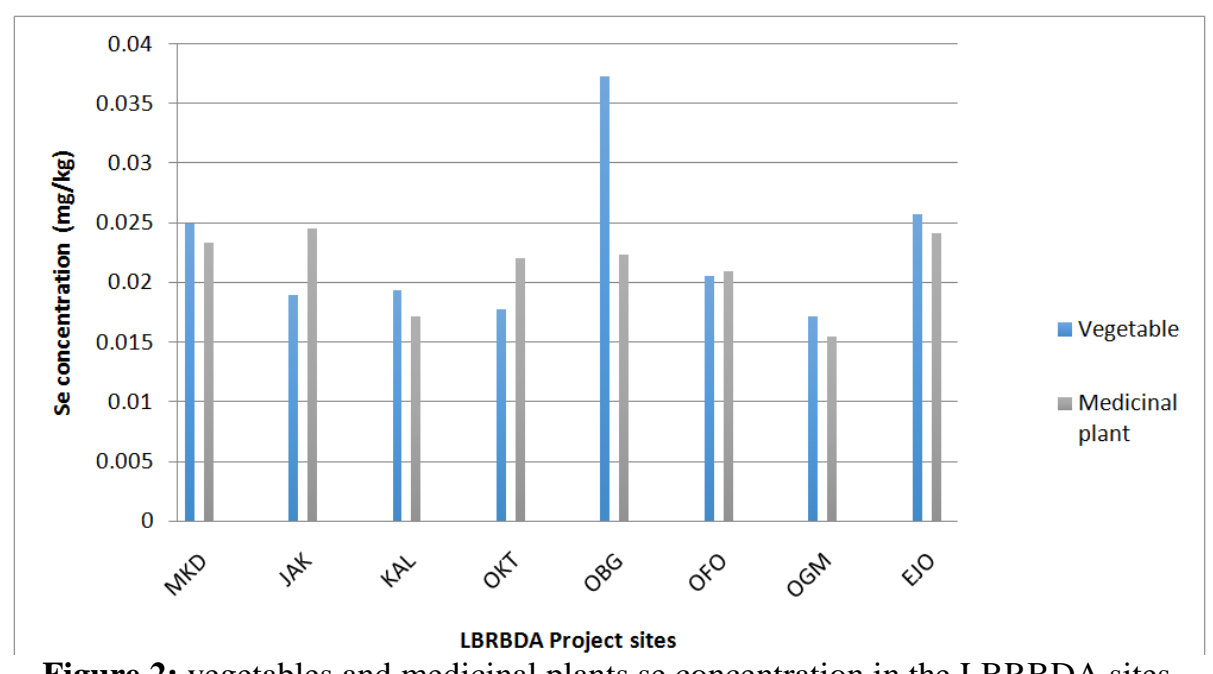

Figure 2: vegetables and medicinal plants se concentration in the LBRBDA sites

The average concentration of Se in both medicinal plants and vegetables combined in the entire site was found to be $217.0 \times 10^{-4} \pm 0.0105 \mathrm{mg} / \mathrm{kg}$. Soil Se concentration values in the entire study area range $1.0 \mathrm{x}$ $10^{-4}-97.0 \times 10^{-4} \mathrm{mg} / \mathrm{kg}$. This variation is expected as species and the variety as well as geographical origin appears to be the main determinants in the selenium content of vegetable plants [35]. The trend of Se, across the vegetable plants from the eight sites was as follows: Agatu, OBG >Ibaji, EJO >Makurdi, MKD >Idah, OFO $>$ Katsina Ala, KAL >Kwande, JAK >Otukpo, OKT >Bassa, OGM (Fig. 2). There was no significant difference in Se levels between medicinal plants and vegetables $(\mathrm{P}>0.05)$. Several species of plants growing on soil of the LBRBDA had markedly different Se concentrations [36, 37]. Low level of vegetable and medicinal plant selenium that was observed in Oguma (Bassa LGA), OGM and Katsina Ala, KAL sites might be due to low availability of soil Se [38]. Results obtained for both Vegetables and Medicinal plants in Figure 2, has shown a very low Se concentration as compared with literature data and this might be an indication that these plants have poor Se uptake capacity from the soil where the plants are grown [39].

Se concentration of Saccharum officinarium (Sugar cane) as depicted in virtually all sites, gave higher concentrations as compared to other plant species in the same sampling location. This is an indication that Saccharum officinarium might be better accumulators of selenium. Generally, the capacity for selenium uptake varies among plant species [40, 41].

The trend in medicinal plants Se concentration across the entire sites was as follows: Kwande, JAK $>$ Ibaji, EJO >Makurdi, MKD > Agatu, OBG >Otukpo, OKT >Idah, OFO>KatsinaAla, KAL >Bassa, OGM (Fig. 2). Analysis of variance has shown that Se concentrations obtained in vegetables have no significant difference on medicinal plants. At 0.05 level of significance, $\mathrm{T}_{\mathrm{cal}}<\mathrm{T}_{\mathrm{tab}}$ implies that there is no statistical difference in the selenium level in both medicinal and edible plants at low value of variation coefficient of $0.008 \%$, the experiment was considered reliable. Selenium concentration in soil from selected sites of the Lower Benue River Basin Development Authority (LBRBDA) project sites are shown in Table 3. 
Table 3: Soil Se Concentration in the Lower Benue River Basin Development Sites, Nigeria

\begin{tabular}{|l|l|l|l|l|l|l|l|l|l|}
\hline $\begin{array}{l}\text { S/N } \\
\text { o }\end{array}$ & Sites $\dagger$ & $\mathbf{1}$ & $\mathbf{1}$ & $\mathbf{2}$ & $\mathbf{3}$ & $\mathbf{5}$ & $\mathbf{6}$ & \multicolumn{2}{c|}{ Range } \\
\hline 1. & MKD & 0.0040 & 0.0033 & 0.0025 & 0.0014 & 0.0036 & NA & $0.0014-0.0040$ & $0.0028 \pm 0.0011$ \\
\hline 2. & JAK & 0.0045 & 0.0014 & 0.0062 & 0.0071 & NA & NA & $0.0014-0.0071$ & $0.0048 \pm 0.0025$ \\
\hline 3. & KAL & 0.0054 & 0.0097 & 0.0037 & 0.0069 & 0.0047 & NA & $0.0037-0.0097$ & $0.0063 \pm 0.0031$ \\
\hline 4. & OKT & 0.0062 & 0.0026 & 0.0064 & 0.0032 & 0.0029 & NA & $0.0026-0.0064$ & $0.0046 \pm 0.0020$ \\
\hline 5. & OBG & 0.0053 & 0.0032 & 0.0063 & NA & NA & NA & $0.0032-0.0063$ & $0.0049 \pm 0.0016$ \\
\hline 6. & OGM & 0.0046 & 0.0037 & 0.0051 & 0.0037 & 0.0028 & 0.0036 & $0.0028-0.0058$ & $0.0039 \pm 0.0008$ \\
\hline 7. & EJO & 0.0048 & 0.0036 & 0.0045 & 0.0075 & 0.0030 & 0.0034 & $0.0030-0.0075$ & $0.0045 \pm 0.0016$ \\
\hline 8. & OFO & 0.0036 & 0.0073 & 0.0016 & 0.0001 & 0.0044 & 0.0049 & $0.0001-0.0073$ & $0.0037 \pm 0.0025$ \\
\hline Total average soil Se concentration
\end{tabular}

$†$ MKD Makurdi (Makurdi LGA) JAK Jato Aka (Kwnde LGA) KAL KatsinaAla(KatsinaAla LGA) OKT Okete (Otukpo LGA) OBG Obagaji (Agatu LGA) OGM Oguma (Bassa LGA) EJO EjuleOjebe (Ibaji LGA) OFO Oforachi (Idah LGA) SD:Standard deviation. NA: Not Analysed

Soil selenium concentrations of the entire sample locations studied indicates a very low soil Se concentration. The trend of soil selenium concentration was as follow: Katsina KAL > Ibaji EJO > Kwande JAK >Otukpo OKT $>$ Agatu OBG > Bassa OGM >Makurdi MKD. Soil selenium range in the eight locations was $1.0 \times 10^{-4}-97.0 \mathrm{x}$ $10^{-4} \mathrm{mg} / \mathrm{kg}$. The average concentration of soil selenium in these locations was $44.0 \times 10^{-4} \pm 0.0020 \mathrm{mg} / \mathrm{kg}$. This point to the fact that soil Se concentrations in these sites would not be toxic when new seeds are planted, and several crops could be grown and supplemented with sodium selenate salts in the same soil in order to improve the soil Se concentration. OFO, Oforachi (Idah LGA), site recorded the lowest soil Se concentrations with $1.0 \mathrm{x}$ $10^{-4} \mathrm{mg} / \mathrm{kg}$. Low soil Se concentration observed, could due to the low soil Se in the site [43]. The low average soil Se concentration observed in the entire sites could be as a result of top soil erosions where Se partitioned itself. The trend followed an observation made by Gil et al., (2004) that soil Se decreases from high land to lowland. The result obtained from the study conforms to their observations bearing in mind that the Benue trough, which is within the lowland areas. Vegetable plant and soil Se concentration has shown weak negative correlation at 0.008 using Pearson Correlation. Average $\mathrm{pH}$ value obtained in the sites of the LBRBDA was $5.08 \pm 0.81$ and the range was $4.10-6.80$, Average soil organic matter was $6.7 \pm 1.42 \%$ and soil conductivity was $102.87 \pm 16.96 \mu \mathrm{Scm}^{-1}$.

This is more acidic in nature than basic and it explains the low soil Se concentration being observed in the region. According to Mikkelsen and Wan, (1990) selenium availability in soil is reduced at increased clay content, $\mathrm{Fe}_{3} \mathrm{O}_{2}$, Organic, presence of competitive ions, and decreased $\mathrm{pH}[45,46]$. KAL, Katsina Ala, site has the highest mean soil Se concentration of $63.0 \times 10^{-4} \pm 0.0031 \mathrm{mg} / \mathrm{kg}$ and this could be the result of soil Se availability in the site [47]. The $\mathrm{pH}$ is the most important of the soil properties affecting plant uptake resulting in greater availability of selenium at increasingly alkaline conditions [40]. The entire sites have an average soil $\mathrm{pH}$ $5.57 \pm 1.16$ and $\mathrm{pH}$ is the most important of the soil properties affecting plant uptake resulting in greater availability of selenium at increasingly alkaline conditions [40, 47]. Products of microbiological activity like dimethyl selenides which are organic Se compounds are volatile. This is a way by which selenium is depleted from the soil by vaporization [48].

\subsection{Discussion}

Data on the Se content in vegetable plants (medicinal plants, vegetables) and soils obtained were compared with those reported from other countries found to be in the same range as reported in some literature data. Range of vegetable Se concentrations $(\mathrm{mg} / \mathrm{kg})$ in the entire sites was $43 \times 10^{-4}-624.0 \times 10^{-4}$ and this is comparable to study carried out by Khairia, (2009) with a range of $1.0 \times 10^{-3}-67.0 \times 10^{-3} \mathrm{mg} / \mathrm{kg}$ Se for cabbage. Low Soil Se concentrations in the selected locations within the lower Benue river basin project sites observed was $1.0 \times 10^{-4}-97.0 \times 10^{-4} \mathrm{mg} / \mathrm{kg}$ and this is comparable to study carried out by Plant et al., (2003) whose range was $<1.0 \times 10^{-3}-7520.0 \times 10^{-3} \mathrm{mg} / \mathrm{kg}$ of soil Se. OFO, Oforachi (Idah LGA) site recorded the lowest soil Se concentrations with $1.0 \times 10^{-4} \mathrm{mg} / \mathrm{kg}$. Bioavailability of soil Se may have fallen in these sites. This could be as a result of erosions and acid rain as they can deplete Se concentrations [40]. This was followed by MAK, Makurdi (Makurdi LGA) and JAK, Jato Aka (Kwande LGA) sites with each $14.0 \times 10^{-4} \mathrm{mg} / \mathrm{kg}$ while KAL, Katsina Ala (Katsina Ala LGA) recorded the highest soil Se concentration $197.0 \times 10^{-4} \mathrm{mg} / \mathrm{kg}$. Least average vegetable Se concentrations were observed in JAK site $\left(190.0 \times 10^{-4} \pm 0.0091 \mathrm{mg} / \mathrm{kg}\right)$ followed by KAL site with $194.0 \times 10^{-4}$ $\pm 0.0128 \mathrm{mg} / \mathrm{kg}$. Stems of Saccharum officinarum recorded the highest level of selenium in each of the sampled sites of LBRBDA. Saccharum officinarum could be one plant capable of high Se accumulating ability. Low level of selenium that was observed in the sites might be due to leaching of essential minerals from soils and this could have resulted to losses of available selenium in the soil for plant uptake [51, 38, 39]. According to Winter 
and Gupta, (1979) classification, total plant Se content below $0.05 \mathrm{mg} / \mathrm{kg}$ connotes selenium deficiency [52]. Based on this observation, average vegetable Se level in the LBRBDA project sites markedly show deficiency in Se. Microorganisms play an important role in Se transformations in the soil. They are capable of transforming the absorbed selenite into organic compounds or inorganic selenate [42]. The trend followed an observation made by Gil et al., (2004) that soil Se decreases from high land to lowland [43]. The result obtained from the study conforms to their observations bearing in mind the Benue trough, which lies in the lowland areas. According to Mikkelsen and Wan, (1990) selenium availability in soil is reduced at increased clay content, $\mathrm{Fe}_{3} \mathrm{O}_{2}$, Organic, presence of competitive ions, and decreased $\mathrm{pH}$. Major determinant of Se status in humans is the level of available Se in soil where plants are grown and animals raised [44, 45, 46]. Results from this study have indicated that $\mathrm{Se}$ in agricultural soils of LBRBDA project sites analyzed were below deficiency classification of $0.05 \mathrm{mg} / \mathrm{kg}$ [43, 53]. To maintain good health, the World Health Organization (WHO) recommends minimum selenium oral intakes of 33-34 $\mu \mathrm{g}$ /day for adult males and 25-26 $\mu \mathrm{g} /$ day for adult females (35-42 $\mu \mathrm{g} / \mathrm{day}$ for lactating females). These intakes are equivalent to $0.47-0.49 \mu \mathrm{g} / \mathrm{kg} \mathrm{bw} / \mathrm{day}$ for adult males, $0.42-0.43 \mu \mathrm{g} / \mathrm{kg} \mathrm{bw} /$ day for adult females and $0.58-0.7 \mu \mathrm{g} / \mathrm{kg}$ bw/day for lactating females (assuming an adult male bodyweight of 70kg and female body weight of $60 \mathrm{~kg}$ ) [54-55].

\section{Conclusion}

Levels of selenium in soils, medicinal plants and vegetables within Lower Benue River Basin Development Authority Project Sites were determined using UV-visible spectrophotometric method. Precision and accuracy of the method used was studied by analyzing the solution containing known amounts cited reagents within the Beer's law limit. The lower values of standard deviation indicated the high accuracy of the methods Selenium found in this study is far below most of the reported literature level in Soils, and vegetables plants. The low level of Se in the entire site indicates that these soils have deficiency in Se accumulation. The trend in the concentration of selenium in soil was as follow: Katsina, >Ibaji, >Kwande, >Otukpo, >Agatu, $>$ Bassa, >Makurdi, while the trend for Se concentration in medicinal plants from the eight sites was Kwnde $>$ Ibaji $>$ Makurdi $>$ Agatu $>$ Otukpo $>$ Idah $>$ Katsinal $>$ Bassa. Level of selenium obtained in stems of $\mathrm{S}$. officinarum from virtually the entire sites has shown a higher value compared to other vegetable species in the sites. The study revealed that the LBRBDA project sites is impacted with very low Se which could be as a result of climatic, weather and geological formation in the area. Low Se concentration observed in medicinal plants, vegetables and soils were far below permissible limits set by WHO/FAO/IAEA. It is apparent that many people in the area might have too little Se to support maximum selenoenzyme expression.

\section{Acknowledgement}

The authors are grateful to Lower Benue River Basin Development Authority (LBRBDA) for their support.

\section{References}

[1]. G.F. Combs. Food System-Based Approaches to Improving Micronutrient Nutrition: The Case for Selenium. Biofactors,12:2000, $39-43$.

[2]. M.B. Zimmerman, and J. Kohrle. The Impact of Iron and Selenium Deficiencies on Iodine and Thyroid Metabolism: Biochemistry and Relevance to Public Health. Thyroid.12:2002, 867-78.

[3]. J. Kohrle, F. Jakob and B. Contempre,. Selenium, the thyroid, and the endocrine system. Endocrin Reviews. 26:2005, 944-84.

[4]. C.D. Thomas. Assessment of Requirements for Selenium and Adequacy of Selenium Status: A Review. European Journal of Clinical Nutrition,58:2004, 391-402.

[5]. S.B. Goldhaber. Trace Element Risk Assessment: Essentiality vs. Toxicity. Regulatory Toxicology and Pharmacology.38:2003, 234-42.http://www.nal.usda.gov/fnic/foodcomp/Data/SR16/sr16.html).

[6]. C.G. Fragra. "Relevance, Essentiality and Toxicity of Trace Elements in Human Health", Molecular Aspects of Medicine, 26:2005,235-244.

[7]. M. P. Rayman. The Importance of Selenium to Human Health. Lancet,356:2000, 233-241.

[8]. D. R Ellis, and D. E.Salt, Plants, Selenium and Human Health. Current Opinion in Plant Biology 6:2003, 273-279.

[9]. E.Altekin, C. Coker, A.R. Sisman,, B. Onvural, F. Kuralay, and O. Kirimli, The Relationship Between Trace Element and Cardiac Marker in Acute Coronary Syndromes. Journal of Trace Element Medical Biology. 18:2005, 235-242.

[10]. F. Kosar, I.Sahin, H.Taskapan, and S.Cehreli, Trace Element Status (Se, Zn, and Cu) in Heart Failure. AnadoluKardiolDerg. 6:2006, 216-220.

[11]. N.Singhal, and J.Austin, Clinical Review of Micronutrients in HIV Infection. Journal of International Association of Physicians AIDS Care.1:2002, 63-75.

[12]. M.A.Beck, O.A.Levander, and J. Handy, Selenium Deficiency and Viral Infection. Journal of nutrition,133:2003, 1463-1467

[13]. S.Shao, and B.Zheng, The Biochemistry of Selenium in Sunan Grassland, Guansu, Northwest China, casts Doubt on 'The Belief that Marco Polo Reported Selenosis for the first time in History' Environmental Geochemistry and Health. 30(4):2008, 307-314.

[14]. N. Chizuru, R.Uauy, S.Kumanyika, and P.Shetty, "The joint WHO/FAO expert consultation on diet, nutrition and the prevention of chronic diseases: process, product and policy implications." Public health nutrition7(1a ):2004, 245-250.

[15]. T.Brady, 'New Technology and Skills Shortages: Problems of Measurement' in Applied Psychology: An International Review, 39 (2), 1990, 223-236,

[16]. H. F. Mayland, L. F James, K. E.Panter, and J. L. Sonderegger, Selenium in Seleniferous Environments. In: Selenium in Agriculture and Environments, Ed. L. W. Jacobs, Soil Science America Special Publication, 23:1989, 15-50. 
[17]. M.Spadoni, M.Voltaggio, M.Carcea, E. Coni, A.Raggi, and F.Cubadda, Bioaccessible Selenium in Italian Agricultural Soils: Comparison of the Biogeochemical Approach with a Regression Model based on Geochemical and Pedodimatic Variables. Science of the Total Environment376:2007, 160-177.

[18]. L.D.Timmerman, N.Waegeneers, C.Thiry, G.D.Laing, F.Tack, and A.Ruttens, Selenium Contents of Belgian Cultivated Soils and its Uptake by Field Crops and Vegetables. Science of the Total Environment 468:2014, 77-82.

[19]. H.F. Li, S.P. McGrath, and F.J.Zhao, Selenium uptake, translocation and speciation in wheat supplied with selenate or selenite. New Phytologist, 178(1): 2008, pp.92-102.

[20]. C.Kahakachchi, H.T.Boakye, P.C.Uden, J.F.Tyson, Chromatographic speciation of Anionic and Neutral Selenium Compounds in Se-accomulating Brassica juncea (Indian mustard) and in Selenized yeast. Journal of Chromatogram Acta, 1054:2004, 303-312.

[21]. A.M.Zayed, C.M. Lytle, N.Terry, Accumulation and volatilization of different chemical species of selenium by plants. Planta. 206:1998, 284-292,.

[22]. M.P.Longnecker, P.R.Taylor, O.A. Levander, M.Howe, C.Veillon, P.A.McAdam, K.Y.Patterson, J.M.Holden, M.J.Stampfer, J.S.Morris, and W.C.Willett, Selenium in Diet, Blood, and Toenails in Relation to Human Health in a Seleniferous Area. American Journal of Clinical Nutrition,53:1991, 1288-94.

[23]. J.W.Finley, C.D.Davis, and Y.Feng, Selenium From High Selenium Broccoli Protects Rats From Colon Cancer, Journal of Nutrition, 130:2000, 2384-2389.

[24]. S.E.O.Abayomi, and O.Adedeji, The Role and Place of Medicinal Plants in the Strategies for Disease Prevention. Africa Journal of Traditional Complement Alternative Medicine; 10(5):2013, 210-229.

[25]. R.Ernest, Medicinal Plants and Traditional Medicine in Africa: Constraints and Challenges. Sustainable Development International, 2000, 179-184.

[26]. O.Osowole, E.Ajaiyeoba, O.Bolaji, D.Akinboye, O.Fawole, C.G.Gbotosho, O.Ogbole, J.Ashidi, O.Abiodun, C. Falade, W.Sama, O.Oladepo, O.Itiola, and A.Oduola, A Survey of Treatment Practices for Febrile Illnesses Among Traditional Healers in the Nigerian Middle Belt Zone. African Journal of Traditional Complementary and Alternative Medicines. 2(3):2005, 337-344.

[27]. N.Sharma, R.Prakash, A.Srivastava, Profile of selenium in soil and crops in seleniferous area of Punjab, India by neutron activation analysis. Journal of Radioanalytical Nuclear Chemistry 281:2009, 59.

[28]. A.Bashorun, P.Nguku, I.Kawu, E.Ngige, A.Ogundiran, K.Sabitu, A.Nasidi, and P.NsubugaA description of HIV prevalence trends in Nigeria from 2001 to 2010: what is the progress, where is the problem? Pan African Medical Journal.18 (1):2014, 3.

[29]. S. Zarmai, I.S.Eneji and R.Sha'Ato, "Analysis of Selenium Content in Root and Tuber Plants in Central Nigeria," American Journal of Analytical Chemistry, 4 (12), 2013, pp. 739-743.

[30]. Y.Saidu, S.Alhaji, M.Lawal, S.Bilbis, and B.M.Sani, "Inhibitory activity of fractions of Sennanigricans toward protein tyrosine phosphatase 1B and dipeptidyl peptidase IV." Journal of Medicinal Plants Research10(18):2015, 242-247.

[31]. A.Oravee, Lower and Upper River Benue River Basin and Rural Development Authority: A Comparative Study. Research on Humanity and Social Science, 5(13):2015, 11-16.

[32]. J.O.Akanmu, O. Eluwa, and I.Ekpo. "Chronicles of river basin management in Nigeria." International Congress on River Basin Management. 2007, 106-114.

[33]. I.B.Fatoye, and Y.B.Gideon, Geology and Mineral Resources of the Lower Benue Trough, Nigeria. Advances in Applied Science Research, 4(6): 2013, 21-28.

[34]. L.Krishnaiah, K.Suresh, K.Suvardhan, and P.Chiranjeevi, "Simple Spectrophotometric Determination of Traces of Selenium in Environmental Samples" in Martin J. Bunch, V. Madha Suresh and T. VasanthaKumaran, eds., Proceedings of the Third International Conference onEnvironment and Health, Chennai, India, 15-17 December, 2003. Chennai: Department of Geography, University of Madras and Faculty of Environmental Studies, York University. 2003, Pages 217-225.

[35]. I.C.Olife and B.A.Anajekwu, Iodine and Selenium Distribution in the Local Environment of Selected Villages in Anambra State, Nigeria. Journal of Natural Sciences Research, (3)5:2013, 116-118.

[36]. S.C.Maja, Selenium in Soil. Proceedings for Natural Sciences, MaticaSrpska Novi Sad,104:2003, 23-37.

[37]. P.Smrkolj, V. Stibilj, and I.Kreft, and M.Germ, Selenium Species in Bulkwheat Cultivated with Foliar Addition of (SeIV)and various levels of UV-B radiation." Food Chemistry 96(4):2005, 675-681.

[38]. F.J.Zhao, F.J.Lopez-Bellido, C.W.Gray, W.R.Whalley, L.J.Clark, and S.P. McGrath. Effects of Soil Compaction and Irrigation on the Concentrations of Selenium and Arsenic in Wheat Grains. Science of Total Environment,372:2007, 433-439.

[39]. N.Terry, A.Zayed, M.P.DeSouza, and A.S.Tarun, Selenium in Higher Plants. Annual Review: Plant Physiology. Plant Molecular Biology, 51:2000, 357-366.

[40]. P.G.Zhang, T.J.Ganje, A.L.Page, and A.C.Chang, Growth and Uptake of Selenium by Swiss Chard in Acid and Neutral Soils, Journal of Environmental Quality, 17:1988, 314-316.

[41]. Y.Shikha, G.Saurabh, P.Ranjana, S. Julian and T.P.Nagaraja, Selenium Uptake by Allium cepaGrown in Se- spiked Soils. American- EurasianJournal of Agriculture and Environment Science,2(1):2007, 80-84.

[42]. J.W.Doran, Microorganisms and the Biological Cycling of Selenium. P.1-32. In: K.C.Marshall (ed.) Advanced Microbialecology, 1982.Vol. 6. Plenum Press, New York.

[43]. S.Gil, S.Hevia, M.Dallorso, and S.Resnizky, Selenium in Bovine Plasma, Soil and Forage Measured by Neutron Activation Analysis. ArqentinaBrasilian Medical VetnaryZootechnology. 56(2):2004, 264-266.

[44]. R.L.Mikkelsen, H.F.Wan, The Effect of Selenium on Sulfur Uptake by Barley and Rice, Plant and Soil, 121: 1990, 151-153.

[45]. M.P.Rayman, The Argument for Increasing Selenium Intake. Proceedings of the Nutrition Society61: 2002, $203-215$.

[46]. G.F.Combs, L.C. Clark and B.W.Turnbull, An Analysis of Cancer Prevention by Selenium. BioFactors.14:2001, 153-9

[47]. R.L.Mikkelsen, A.L.Page, and F.T.Bingham, Factors Affecting Selenium Accumulation by Agricultural Crops. Chapter 4, 65-94. In: Selenium in Agriculture and the Environment. Jacob, L. W. Editor. Soil Science Society of America (SSSA) Special Publication No 23. American Society of Agronomy, Inc. and Soil Science Society of America, Inc. Wisconsin, USA. ISBN 1989,0-891 18-7898.

[48]. W.T.Frankenberger, U.Karlson, Environmental Factors Affecting Microbial Production of Dimrthylselenide in SeleniumContaminated Sediment. Soil Science Society of America Journal, 53(5):1989, 1436-1442.

[49]. M.A.Khairia, Selenium Content in Selected Foods from Saudi Arabian Market and Estimation of Daily Intake. Arabian Journal of Chemistry, 2:2009, 95-99.

[50]. J.A.Plant, D.G.Kinninburg, P.L.Smedley, F.M.Fordyce, and B.A.Klink, Arsenic and Selenium. In: Lollar, B.S. (Ed.), Treatise on Geochemistry, Environmental Geochemistry, 2003, Volume 9: Elsivier

[51]. H.K.Ahmed, Differences Between Some Plants in Selenium Accumulation from Supplementation Soils with Selenium. Agriculture and Biology Journal of Nutrition of America.1(5):2010, 1050-1056, 
[52]. K.A.Winter, and U.C.Gupta, Selenium Content of Forages Grown in New Scotia, New Brunswick and Newfoundland. Canadian Journal of Animimal Science,59:1979, 107-111.

[53]. Environment Canada Canadian Soil Quality Guidelines- Selenium, National Guidelines and Standard Office, Ottawa 2002, on http://www.ec.gc.ca/ceqgrcq/English/pdf/Gaag-Selenium-epdf (accessed 01-17-2013).

[54]. UK EGVM Revised Review of selenium. United Kingdom Expert Group on Vitamins and Minerals, 2002.

[55]. WHO/FAO/IAEA. Trace Element in Human Nutrition and Health'. World Health Organization, Geneva, 1996, 6-10. 